\title{
From capacity to capability? Rethinking the PRME agenda for inclusive development in management education
}

\author{
Authors: \\ Dr Jill Millar ${ }^{1}$ \\ Prof Juliette Koning ${ }^{1}$ \\ Affiliation: \\ ${ }^{1}$ Oxford Brookes \\ University \\ Correspondence to: \\ Dr Jill Millar, \\ Oxford Brookes Business \\ School, \\ Headington Campus \\ CLC 1.27, \\ Oxford, \\ OX3 0BP \\ United Kingdom
}

Tel:

+441865485418

E-mail:

jmillar@brookes.ac.uk

j.koning@brookes.ac.uk

DOI:

$10.15249 / 12-1-163$

Keywords:

inclusive development; PRME; Sen; capabilities; management education; higher education; human well-being

\section{Abstract}

This article assesses whether developments in management education, particularly PRME (the United Nations Principles for Responsible Management Education), can contribute to the promulgation of an inclusive development that moves beyond the discourse of 'growth' and 'income'. Based on an exploration of topical literature on inclusive development, Amartya Sen's capability approach, and the principles themselves, we argue that PRME in its current form reproduces a dominant market logic. It lacks the sensitivity to difference as captured in the plural quality of the capability approach. In response, we suggest a PRME agenda for management education that contributes to inclusive development as human well-being, rewriting it in terms of capabilities.

\section{Introduction}

An increasing concern with ideas of equity and justice is expressed through the label 'inclusive' as applied to social development and to capitalism. This concern represents a moral reframing of economic strategy and practice, a reframing that extends beyond business practice to business education. Thus, the United Nations Principles for Management Education (UNPRME or PRME) anticipates that Business Schools will take as their purpose the development of "future generators of sustainable value" working for "an inclusive and sustainable global economy" (Figure 1 below), encapsulating the understanding that such 'inclusivity' is desirable. We problematise this understanding on a variety of levels, arguing that it involves the dis-embedding of a particular approach to economic practice, rescaling it to universal dimensions; that 
this process of rescaling acts to exclude subaltern perspectives, thus undermining claims to inclusivity; and that PRME and similar mechanisms reinforce a specific normative agenda which reproduces, rather than challenges current global inequalities and injustices.

The objective of this article is thus to contribute to alternative articulations of inclusive development (beyond the discourse of 'growth' and 'income') for higher education purposes. We will focus on PRME to assess to what extent current developments in management education can fulfil the promise of such alternative interpretations. Our article is based on explorations of current academic and policy literatures around inclusive development, Amartya Sen's capability approach, PRME and management teaching in higher education. We used these search terms in Google Scholar and other databases to identify a relevant set of articles, which allowed us to articulate current positions as to the meanings of inclusive development, develop a conceptual framework around Sen's work and subsequently assess if PRME and management education make a contribution to inclusive development.

We start the article by drawing attention to limitations of mainstream ideas of inclusivity and social justice, providing an alternative conceptual framework based on the work of Sen. Applying this framework to PRME and management education in subsequent sections of the article, we identify what is missing, in particular a sensitivity to different values and expectations as captured in the radically plural quality of Sen's capabilities approach. We show that for PRME to be able to contribute to inclusive development there is a need to re-open the debate which PRME itself effectively closed down, about the nature and purpose of management education and practice. The article culminates in suggestions for a more inclusive PRME agenda, rewriting it in terms of capabilities.

\section{A prelude to conceptualising inclusive development}

Before it can be assessed whether management education, as it is currently perceived and structured (globally), has something to contribute to inclusive development, it is important to come to a better understanding of the conceptualisation of 'inclusive development' itself. For this we need to explore its heritage. This heritage, we suggest, can be traced back to the Brundtland Report and subsequent articulations of sustainable development, together with more recent concerns with ideas of inclusive growth. Significantly, these ideas have combined to produce a particular understanding of inclusive development. Gupta and Pouw (2017:104) comment that "inevitably, if neoliberalism and laissez-faire has political and economic weight, the interpretation and implementation of sustainable development leans towards growth first, as is dictated by the market".

The Brundtland Report (Our Common Future, 1987) is well known for articulating the linkage of equity (people), environment (planet), and economic growth (prosperity). Nearly 30 years after this report, the heads of government, who adopted the 2030 Agenda for Sustainable Development, pledged to be "committed to achieving sustainable development in its three dimensions - economic, social and environmental - in a 
balanced and integrated manner" (United Nations General Assembly, 2015:par 2). Like the Brundtland Report, the 2030 Agenda stresses the importance of equity to ideas of sustainable development. Arguably this current emphasis on equity is driven by what might be seen as a crisis of confidence and/or legitimacy in capitalism, as a recent quotation from the World Economic Forum (WEF, 2017:vii) suggests: "Can rising incountry inequality be satisfactorily redressed within the prevailing liberal international economic order? Can those who argue that modern capitalist economies face inherent limitations in this regard - that their internal 'income distribution system' is broken and likely beyond repair - be proven wrong?" At the heart of the discussion lies the question whether capitalism can deliver fairer societies.

In responding to this question, the WEF Report (2017:xii) links equity to economic growth:

Efficient markets and macroeconomic stability are essential for economic growth. But how well growth benefits society as a whole depends on the framework of rules, incentives, and institutional capacities that shape the quality and equity of human capital formation.

The report argues that the problem is not with the capitalist system itself, but with the way in which the benefits of growth are diffused in different countries. As a consequence, it is said that there needs to be a greater focus on inclusivity, on inclusive growth that is understood as "the translation of growth into broad based expansion of economic opportunity and prosperity", a translation that demands "an economic policy focus going beyond redistribution and education" (WEF, 2017:vii). The report then goes on to outline a detailed framework through which to promote, measure and compare inclusive growth.

What we seem to be witnessing is a growing imbalance between the three key dimensions of sustainable development, that is, the economy, society and the environment, with an over-emphasis on the economy (Gupta \& Viglin, 2016). There is a notable location of the debate within a market logic and current discussions of inclusive growth, inclusive wealth and inclusive economics focus too much on economic indicators and economic performance using macro indicators at the expense of micro realities (Gupta et al., 2015), the WEF 2017 report being a particularly good example of this approach. In addition, current debates are characterised by a short-term, individualist orientation at the expense of the long term and collective well-being. Thus, as Gupta and Viglin (2016:437) suggest, sustainable development and inclusive growth do not yet quite equate to something recognisable as inclusive development.

Central to a reconceptualisation of inclusive development is the importance of a distinction between growth and development. For instance, an Asian Development Bank (ADB) report argues that "the concept of development differs from growth in expanding the focus from income alone to other dimensions of well-being, in particular education and health" (ADB, 2009). Hence, "development brings into play dimensions of wellbeing beyond simply income, while inclusive focuses attention on the distribution of well-being in society" (ADB, 2009:2, italics in original). This position resonates with the arguments, made more recently by Gupta and Viglin (2016), Pouw and Gupta (2017) and Gupta and Pouw (2017), that a move from growth to inclusive growth stays within an 
"income" discourse. Within this conceptualisation inequality and exclusion cannot but remain largely untouched, as "two structural conditions of the development pathways of neoliberal capitalism" (Araos \& Ter, 2017:69).

\section{Inclusive development: a conceptual framework}

Alternative understandings of an inclusive development that address the market logic and top-down nature of the sustainable development discourses are beginning to be promulgated. These understandings are highly relevant to the discussion about inclusive development in/through higher education, and in particular to debates on the role of management education herein as we shall address in more detail below.

Gupta et al. (2015:546) define inclusive development as "development that includes marginalized people, sectors and countries in social, political and economic processes for increased human well-being, social and environmental sustainability, and empowerment". Based on this definition they elaborate a detailed conceptualisation of inclusive development. At its heart is a comprehensive idea of human well-being which, using insights from the Well Being in Developing Countries Research Group, they represent as a state of being in which, with all needs being met, goals can be pursued and a satisfactory quality of life achieved. Further they argue that inclusion involves a concern with non-discrimination and sensitivity to the vulnerable and disadvantaged as well as the economically poor. It demands a valuing of particular local knowledge, a recognition of the social situatedness of processes of inclusion and exclusion driven by local and global relations, and the need for greater participation both in governance and use of social resources (see discussion Gupta et al., 2015:546-547). This focus has, we argue, strong resonances with the work of Amartya Sen. Sen is mentioned by Gupta et al. (2015) and Gupta and Pouw (2017) but only in passing, yet his capability approach provides an important foundation for understandings of inclusive development, a normative framework "for the evaluation and assessment of individual well-being and social arrangements" (Robeyns, 2005:94).

More specifically, Sen's capability approach challenges dominant utilitarian and libertarian approaches to development, which lend themselves to a prioritisation of economic development and fail to grasp individual inequities (Sen, 1999). Instead Sen argues that the focus of development should be on "the freedom to live the kind of life one would like" (Sen, 1989:41). The idea of living such a life is tied to two important notions: functionings and capabilities. Functionings are ways of being or doing that an individual may value, while capabilities are defined as "the real opportunity that we have to accomplish what we value ... the various combinations of functionings (beings and doings) that the person can achieve" (Sen, 1992:49). Elsewhere, Sen explains: "Capability is thus a kind of freedom: the substantive freedom to achieve alternative functioning combinations (or ... lifestyles)" (1999:75).

The capability approach has three important qualities that contribute to a conceptual framework for inclusive development. Firstly, in prioritising ways of being, Sen reverses the dominant development focus on poverty and income growth. Income is no longer 
an end, but a means to an end, and one among many variables that contribute to an individual's capabilities (1999:90). Thus, the approach constitutes a substantive critique of resource-based approaches to 'measuring' well-being (and development), because of unequal access to convert resources into something valuable.

Secondly, functionings and capabilities are, as Sen suggests "inescapably pluralist" (Sen, 1999:76). He makes the point that some functionings, ways of being, can be seen to be more important than others; equally the value of freedoms in relation to the actual way of being achieved may be debated, and finally, while capabilities or freedoms are important within his approach, other relevant concerns such as rules and procedures are not excluded. Sen's conceptualisation, then, has an openness of definition, which creates scope for inclusion of particular ways of being that are seen as valuable, as well as an ability to take into account local context and conditions in identifying the freedoms that are required to achieve a valuable life.

Thirdly, Sen's approach contains the explicit expectation that public discussion and social participation are required to explore the valuation of functionings and capabilities in different contexts and regions (Sen, 1999:110).

\section{Inclusive development and management education}

Building on this conceptual framework of inclusive development we will now consider ideas of 'inclusion' in discourses currently gaining ground in Business Schools. In so doing we explore the potential contribution of management education to inclusive development. Our focus is on PRME for three reasons: because of the explicit engagement of PRME with values in Business School activities; because of the growing global influence of PRME; and because of PRME's conceptualisation of the purpose of management education as contributing to inclusive development and growth. We will first say a little more about PRME before going on to evaluate its potential to contribute to forms of inclusive development understood in terms of Sen's capability approach.

\subsection{PRME and management education}

Following the 2008 financial crisis a growing body of work has been expressing concerns with the nature and content of management education. It has been argued that ethics have been squeezed out; that management pedagogy relies upon abstract modelling and constructed case studies to inculcate standardised and shallow-rooted analytical perspectives (Huhn, 2014); and that perspectives are burdened by radical and limited understandings of human beings as inevitably both rational and self-interested (Elegido, 2009; Huhn, 2014). Perhaps as a result, or perhaps because of the sort of people attracted to business degrees, business students have been found to be less generous, more likely to cheat in examinations, and more likely to focus on profit rather than people when working in business, than their peers (Elegido, 2009). Indeed, as Podolny (2009) comments, business students (or American MBA students at least) are more concerned with making money than making a difference. Further, beyond pedagogy 
and people, Painter-Moreland (2015:69) argues that what is lacking in management education is vision, "a holistic, systemic understanding [that] is central to responding to the sustainability agenda ... this is where Business Schools fall short".

The PRME initiative constitutes a direct response to these perceived problems, focusing on the role of students as future participants in the global economy, reasserting a value base for management and management education and identifying a broad agenda for the pedagogy, research and the external relations of Business Schools.

\section{The PRME Principles}

As institutions of higher education involved in the development of current and future managers we declare our willingness to progress in the implementation, within our institution, of the following Principles, starting with those that are more relevant to our capacities and mission. We will report on progress to all our stakeholders and exchange effective practices related to these principles with other academic institutions:

PRME Principle 1. Purpose: We will develop the capabilities of students to be future generators of sustainable value for business and society at large and to work for an inclusive and sustainable global economy.

PRME Principle 2. Values: We will incorporate into our academic activities and curricula the values of global social responsibility as portrayed in international initiatives such as the United Nations Global Compact.

PRME Principle 3. Method: We will create educational frameworks, materials, processes and environments that enable effective learning experiences for responsible leadership.

PRME Principle 4. Research: We will engage in conceptual and empirical research that advances our understanding about the role, dynamics, and impact of corporations in the creation of sustainable social, environmental and economic value.

PRME Principle 5. Partnership: We will interact with managers of business corporations to extend our knowledge of their challenges in meeting social and environmental responsibilities and to explore jointly effective approaches to meeting these challenges.

PRME Principle 6. Dialogue: We will facilitate and support dialogue and debate among educators, students, business, government, consumers, media, civil society organisations and other interested groups and stakeholders on critical issues related to global social responsibility and sustainability.

We understand that our own organisational practices should serve as example of the values and attitudes we convey to our students.

Figure 1: PRME principles (PRME, 2017)

In discussing PRME we focus in detail on Principles 1 and 2. As can be seen from the full text of the principles set out in Figure 1 above, these two principles are the foundation on which the PRME agenda is built. Principle 1 identifies the purpose of management education, Principle 2 its guiding value. The other principles (3-6) specify the areas of activity that are required to instantiate Principles 1 and 2 . Thus Principle 1 asserts that the purpose of management education is to enable students to contribute to sustainable 
value. It is this purpose that informs the expectations of curriculum, pedagogy, research and stakeholder interaction set out in the subsequent principles.

Currently, over 650 Business Schools worldwide have adopted PRME (PRME, 2017). Numbers continue to rise, with accreditation bodies (including the AACSB and EFMD) treating adherence to PRME as fulfilling the need for management degree programmes to incorporate ethical perspectives. At the same time the promulgation of PRME has been accompanied by a proliferation of national and international networks, and global and local events. The PRME website identifies nine PRME regional chapters aimed at driving a focus on PRME, PRME champions to act as thought leaders, twelve international special-interest working groups, and an annual cycle of regional meetings and international conferences, all of which, combined with a burgeoning list of academic and practice publications, serve to highlight the increasing significance of the PRME project to management education (PRME, 2017).

\subsection{PRME and inclusive development: a question of purpose}

In PRME Principle 1, we find an explicit articulation of purpose: "We will develop the capabilities of students to be future generators of sustainable value for business and society at large and to work for an inclusive and sustainable global economy." Despite its importance to the PRME project there appears to be a limited focus in the PRME literature on the meaning of "future generators". Indeed, database searches for the term reveal little apart from straightforward reproductions of Principle 1 and (if not excluded) a bevy of engineering texts.

Prandini et al. (2012) attempt an interpretation, linking the term "future generators" to the notion of responsible leadership in Principle 3. In line with the suggestion that Business Schools have failed to produce appropriately educated managers, the authors argue that PRME acts as a manifesto to help shape attitudes and behaviour of business leaders. Further, in order to aid business leaders to "live and practise responsible leadership" (2012:18), Prandini et al. devote considerable space to a detailed cataloguing of the necessary knowledge skills and attributes that Business Schools should aim to instil in their students. If the PRME Inspirational Guide (PRME, 2015) is to be believed, PRME can help to achieve a focus on these qualities. For instance, a report from the Strathclyde Business School states that an undergraduate programme was remodelled inspired by the PRME initiative, which meant that the programme "now develops students, both professionally and individually, so that they are better equipped to enter the workplace and make an immediate positive impact as responsible managers" (2015:18).

Perhaps here we need to pause for thought and look again at the wording of Principle 1, and in particular the use of the term "capability". For Sen, as we have already seen, capability denotes a freedom, an opportunity to do or be what we value. However, in specifying the outcomes of management education, what Principle 1 and the associated literature offer is a particular capability, leading to a particular way of being, a future generator/responsible leader. It is this sense of predetermination (Louw, 2015) that should 
cause concern, the expectation that students will go on to perform the role of manager or leader, and in a specified way. Concern because rather than offering an uncircumscribed notion of the purpose of learning, PRME and its proponents anticipate that management education will enable students to rise to the challenge of being the flexible, team-working, moral and articulate graduates that organisations seek (PRME, 2015:16). In so doing, PRME Principle 1 contributes to an entrenchment of the discourse of employability in Business Schools. Student employability, the expectation that universities will promote economic development through the production of "'oven-ready' graduates", has gained ground among policy makers in the West (Boden \& Nedeva, 2012:46). This entrenchment carries with it a constraint on freedom, albeit one disguised by claims of access and choice. Thus, rather than it being the responsibility of the state, business and society to create the scope and opportunities for jobs, and of employers to pay for vocational training, it becomes the 'choice' of the students to enter a massified higher education system, so as to make themselves 'employable' (and indebted), in order to have a career (Boden \& Nedeva, 2012).

This understanding of the purpose of management education locates PRME within a human capital approach to higher education, an approach which, as Robeyns (2003) points out, is founded on an economic calculation. Education is valued instrumentally as a way of improving individual and social productivity. An important limitation then is that PRME appears to reproduce rather than contest the dominant market logic that we also see in mainstream versions of inclusive development, while at the same time constraining available capabilities (and consequent functionings).

\subsection{PRME, universality and pluralism}

Another important limitation to PRME's ability to drive a focus on inclusive development in management education lies in the claims to universality that appear to be integral to PRME (Louw, 2015). PRME proponents make frequent references to PRME values as being internationally proclaimed or accepted (for example Sobczak \& Mukhi, 2016) in part based on the direct association between PRME and the UN Global Compact (UNGC), expressed in Principle 2: "We will incorporate into our academic activities and curricula the values of global social responsibility as portrayed in international initiatives such as the United Nations Global Compact".

There is, however, (Millar \& Price, 2012) an important difference between international promulgation and universal acceptance. Human rights law, for instance, might be agreed at international level, but rights are not necessarily universally resonant norms, based as they are in enlightenment notions of the social contract, individual will and capacity. Thus, within human rights discourse, a growing series of human rights declarations and conventions (including those incorporated into the UNGC) confer rationally identifiable rights to each and all individuals by virtue of their being human. These rights serve to regulate relations between states and citizens, between citizens, and between individuals and organisations. As a consequence, this conceptualisation of rights reflects a recognisably western normative tradition. 
As Sen (2005:162) argues, there has been a tendency to exaggerate "the differences on the subject of freedoms and rights that actually exist between different societies". In other words, a universal set of human rights may be possible, grounded in values shared across cultures. At the same time, Sen (2005:162) suggests that western conceptualisations of human rights have been prioritised, based in some cases on ideas of western exceptionalism (here Sen cites a particularly egregious example from Huntingdon (1998) in his claim that "a sense of individualism and a tradition of individual rights and liberties" are "unique among civilized societies").

If human rights literature grapples, more or less successfully, with the assumptions underpinning these universal claims, this is less apparent in discussions of PRME (see for instance Alcaraz \& Thiruvattal, 2010; Sobczak \& Mukhi, 2016). This is, we suggest, problematic, in that it leaves no space to discuss or perhaps even recognise the possibility of alternative conceptualisations of the values that should inform management education and practice.

Such an argument might come as a surprise to PRME proponents, leading them to point to the importance of dialogue and debate, highlighted in Principles 5 and 6. Further, the expectation of discussion is embedded in depictions of the way that the initiative has developed: as a network with information sharing at its heart (Godemann et al., 2013; Haertle \& Miura, 2014). In this regard, the ambiguity of the PRME principles is presented as a positive characteristic (Haertle \& Miura, 2014). Thus Principle 2 connects global social responsibility (GSR) to international initiatives 'such as' the UNGC, but leaves unstated what the other initiatives might be, how they relate to the UNGC, and the meaning of GSR as compared to corporate social responsibility (CSR), itself memorably described by De George (2008:74) as a "concept in search of specific content". It appears then that there is scope, as Haertle and Miura (2014:11) claim, for PRME ideas to be debated and "glocalised" so that alternative positions are recognised.

There are however several issues with this argument. Firstly, any debate about PRME is not about what the purposes, values, and activities of management education should be. That debate has already happened, in 2007, when the PRME principles were developed by an "international task force of 60 deans, university presidents and official representatives of leading Business Schools and academic institutions” (PRME, 2017).

Rather, the overwhelming focus of debate in the PRME literature is on how these ideas should best be implemented (Godemann et al., 2013; PRME, 2015), not what they mean and whether they are relevant. This focus leaves underlying assumptions unaddressed. Thus, PRME reflects the expectation that management education and business practice should be socially responsible (see Principle 2). Yet this attribution of social responsibility to business displays a particular, culturally situated, understanding of the relation between business and society. It is one in which broader social responsibilities are seen as additional to, rather than integral within business purpose, building on a founding assumption of economic theory, that rational actors act in terms of their own selfinterest (Del Portal \& De Frutos, 2015). This is an assumption that continues to haunt current social responsibility debates. Equally, alternative understandings of the nature 
and values of economic activity and responsibility are excluded; see for example the work of Verbos and Humphries (2015). Arguably this is less a process of glocalisation as claimed by Haertle and Miura (2014), a process in which the local and the global combine to shape the outcomes of interactions with heterogeneity the end state (Roudometof, 2016:399); it more nearly resembles Ritzer's (2003) notion of 'grobalisation', of a growing, even aggressive push for homogeneity.

What is missing, therefore, is a sensitivity to different values and expectations, a sensitivity captured in the radically plural quality of Sen's capability approach. Although critiqued notably by Nussbaum (2003), for us Sen's approach retains merit. Plurality in Sen's work is driven by the dual quality that he attributes to understandings of justice. Thus, a theory of justice requires both capabilities, which constitute the opportunities that are available to individuals, and also a fairness of process through which the range of possible capabilities and their operation can be identified (Sen, 2005). In conceptualising justice in this way, Sen insists on what Clare and Horn (2010:76) call an "evaluative context of justice". By this is meant a context in which there is an expectation that both capabilities and processes are made the subject of scrutiny from what Adam Smith called "the eyes of the world" (Sen, 2005:163). In other words, opinions on capabilities and processes need to be obtained not only from those directly affected, but from across society and between societies more generally. That context and flexibility are central to Sen's version of justice, is made apparent in his comment, "my own reluctance to join the search for ... a canonical list [of capabilities] arises partly from my difficulty in seeing how the exact lists and weights [of capabilities] would be chosen without appropriate specification of the context of their use (which could vary) ...” (Sen, 2005:157).

From a capability perspective, then, the PRME discourse needs to move beyond an unquestioning acceptance and promulgation of a "canonical list" of values, in order to develop a more inclusive understanding of fairness and equity, as a foundation for the sustainable development and inclusive economy which it seeks to promote (Principle 1).

\section{Rethinking PRME}

The burden of the argument in this article is that for PRME to be able to contribute to inclusive development, there will need to be a change in the terms of the debate. More specifically, what is needed is to re-open a debate, which PRME closed down about the nature and purpose of management education and practice. It is here that Sen's capability approach provides a normative language (Deneulin, 2014) through which to focus discussion, contributing a broader understanding of development in which there can be a plurality of meaning, and an expectation that any such understandings are made the subject of scrutiny through public reasoning. As Deneulin (2014:6) puts it, "the capability approach is essentially about a space for evaluating social arrangements".

Accepting this comment as an invitation, we now consider what a PRME agenda that contributes to inclusive development might look like, rewriting it in terms of capabilities. 
To do so we focus again on Principles 1 and 2 as the foundations upon which an inclusive management education might be built.

\subsection{Principle 1}

A central quality of a rewritten PRME agenda would be an emphasis on going beyond the human capital approach to education, which we suggested was linked to PRME Principle 1. Such a shift in emphasis would mean, as Sen (1999:293-294) suggests, concentrating on "different achievements" arising from education, achievements in addition to employability or overall economic productivity, achievements including "reading, communicating, arguing, ... being able to choose in a more informed way, ... being taken more seriously by others and so on”. This shift from a human capital to a human capability approach to education reflects Sen's concern to reinforce the recognition that human beings are the ends of economic growth, not simply the means (Sen, 1999:295). Indeed, for Sen (1999:296) the direct relevance of education for individual well-being, and its indirect relevance to social change, is as important as any potential contribution of education to economic productivity and wealth.

Walker (2012) and Walker et al. (2009), discuss the implications for higher education of this vision of education. Focusing in particular on student lawyers, doctors and social workers in a South African context, Walker et al. (2009) argue that universities should be spaces in which students can develop capabilities to enable them to live lives that are of value to them. Such capabilities would include the freedom to choose a job that they have reason to value (Walker, 2012:391), but also other capabilities, drawn from Nussbaum's (2003:41) list of "the central human capabilities", which include the capabilities to exercise practical reasoning and affiliation. These capabilities relate to a range of skills and qualities that education can imbue, and involve the ability to conceptualise what is good and engage in critical reflection (practical reasoning), together with the ability to live with, and for others (affiliation).

Encouraging practical reasoning in management education, encouraging the ability to conceptualise what is good and engage in critical reflection would drive a moral focus within the business curriculum. The PRME principles point to what is 'good' by claiming GSR as the underpinning value of management education. In contrast, practical reasoning does not specify what 'good' is, requiring students to debate and develop their own moral positions. Equally, a concern with affiliation would encourage a curriculum that delivers an in-depth understanding of, and openness to, the 'other'. There is no similar recognition of 'the other' on the face of the PRME principles; however, such a recognition would challenge the assumption of self-interest that underlies economic modelling (Elegido, 2009), and underpins the business-case approach to responsibility and sustainability (for example Hart \& Milstein, 2003).

At an individual level, a capability approach releases management students from their predetermined role as "future generators", who "work for a sustainable and inclusive global economy" (PRME Principle 1), creating the potential for a broader range of 
functionings. At the same time however, as pointed out by Sen (1999:18), greater freedom is linked to greater agency, the freedom to act, enabling people both to help themselves and to "influence the world". Walker et al. (2009:567) elaborate this point, arguing that if students develop their capabilities - their freedom through access to higher education - then there is also the social obligation to exercise such freedom to bring about social change. As such, an emphasis on capabilities in management education would directly address Podolny's (2009) concerns that management students are more interested in making money than making a difference, by stressing an idea of duty as a corollary to the opportunities created through undertaking a management degree.

\subsection{Principle 2}

Another quality of a rewritten PRME agenda would be the rethinking of the values that should support management education. From a capabilities perspective, GSR, as articulated in Principle 2, is replaced as a guiding value. Instead the justice of realised, achieved, human well-being (Sen, 1999:18) becomes the measure against which the moral value of economic systems and practices are judged. This contrasts with the narrower and more incomplete focus of dominant ideas of business responsibility that tend to be concerned with the recognition of a defined set of what Nussbaum (2003:39) calls "traditional" rights, or with calculations of economic utility that validate the interests of the majority at the expense of the few, or indeed with the positive social consequences of acting in one's own interests (see Del Portal \& De Frutos, 2015; Anstatt \& Volkert, 2016).

Instead the question becomes: Are businesses contributing to human well-being, in a capabilities sense? More particularly, how far do businesses and the economy support Sen's constitutive freedoms, such as literacy, numeracy and political participation, as well as the avoidance of starvation and premature mortality (Sen, 1999:36)? Finally, to what extent do businesses impinge upon Sen's (1999:38) instrumental freedoms, those that help individuals achieve the ends of development, such as participation in decisions that will affect them, the ability to dissent, access to suitable jobs, markets and a secure environment? Research suggests that current approaches to CSR appear to have a limited positive impact on the basic capabilities of marginalised groups (Newell \& Frynas, 2007; Anstatt \& Volkert, 2016), a negative impact on instrumental freedoms such as the maintenance of social capital and relationships, and ignore the implications for future generations of the environmental consequences of corporate activities (Anstatt \& Volkert, 2016). At the same time, an important insight from these research studies is that where businesses enable participation from local communities in developing CSR strategies, then aspects of human well-being are improved.

This insight links to Sen's (2009:196-197) concern that the identification and prioritisation of valued capabilities should be the subject of a process of public reasoning, in which valuations are defended, participation is encouraged and "serious attention [is paid] to the perspectives and concerns of others". Building on this pluralist perspective it is possible to recognise that alternative conceptualisations of the relation between business and responsibility are available, a recognition that is required in order to achieve 
more inclusive approaches to development. For instance, Kuokannen (2007) discusses distinctive ideas of responsibility articulated by various indigenous peoples. For these groups responsibility is not separable from the person, a voluntary quality (Newell \& Frynas, 2007) that can be applied to 'legal persons' for instance. Rather, responsibility is understood as integral to the human condition, a state that includes the recognition that we are interrelated with all life forms. Thus, it is not a choice but an expectation that we will take responsibility for others in society, both human and non-human. Expressed in terms of capabilities, this sense of an extended responsibility would have a two-fold effect. First, it would demand that businesses, as a matter of justice, do not impinge upon the capabilities of indigenous groups to behave in ways that respect the environment as a part of human society. Second, and more fundamentally, it would demand an acceptance that ideas of social and economic externalities are a work of fiction.

\section{Contributing to inclusive development: ways forward}

Embedding a pluralist approach to human well-being in management education will have its problems, yet it is a necessity if management education is to contribute to inclusive development as understood in this article. Higher education institutions, whether in America or Africa, do not provide a neutral space in which alternative perspectives can flourish, but one deeply imbued with the Western assumptions on which higher education was founded (Kuokannen, 2007:13). In this context local, particular, indigenous ideas and conceptualisations become defined as traditional, static and pre-industrial, as against current Western social structures and practices. In contrast, Western societies are understood to have progressed along a linear, upward development trajectory. These sorts of assumptions are apparent in the conceptualisations underpinning PRME as our analysis in this article suggests.

Further, it has not always been straightforward to implement changes to management education, even among PRME signatories. Rasche and Gilbert (2015) argue that where the adoption of PRME is driven by reputational demands and accreditation criteria, a decoupling of formal policies from day-to-day practices can occur, with one factor being the resistance of staff to the top-down imposition of changes to values, curricula and research focus. As they point out, Business Schools, "depend to a large extent on a change model in which actors themselves have to see the need for change and to act in reflexive ways" (Rasche \& Gilbert, 2015:245).

With the need to persuade academics to teach and research ideas of inclusive development in mind, it may yet be possible to capitalise on the energy around change in management education that is already reflected in the growing PRME community. There is a sense of pride, which is surely not misplaced, in the way that PRME proponents present the initiative as one which has developed into some kind of collaborative community. As articulated by Haertle and Miura (2014:8) "PRME encourages collaborative learning and collaborative innovation on practice in responsible management education, research, and thought leadership". Arguably, this sense of an academic and practitioner community 
with a focus on management education begins to resemble the epistemic communities that Gupta et al. (2005:548) suggest are important elements in securing inclusive development; communities, which "disseminate and contest knowledge, implement instruments of inclusive development and share experiences". It is here that debates about the nature and purpose of management education can be restarted and developed, informed, we would suggest, by a capabilities approach as outlined above.

From this perspective PRME becomes a palimpsest for encouraging a more inclusive approach to development in management education, rather than a vague, yet constraining formula whose combined conceptualisation and implementation serves to perpetuate existing development priorities and ideas of justice.

\section{Conclusion}

This article has used PRME as its core focus to assess whether current developments in management education can contribute to the promulgation of an inclusive development agenda that moves beyond an economic deterministic discourse. Evaluating core principles of PRME against a framework based on Sen's capabilities such as human well-being, pluralism and social participation, the conclusion is that PRME and its contribution to inclusive development through responsible management education is limited; PRME reproduces rather than contests the dominant market logic and PRME values are presented as universal but seem particularly grounded in Western value systems. We propose however that there is scope for rethinking management education, building on the work of Sen and drawing on the energy around changes in management education globally, expressed in the growing PRME community. As a collaborative group, PRME has the potential to challenge its assumptions, reopen the debate on the nature and purpose of management education, and thus the possibility of contributing to more holistic understandings of inclusive development in Business Schools and beyond.

\section{References}

Alcaraz, J. \& Thiruvattal, E. (2010). An interview with Manuel Escudero: The United Nations' principles for responsible management education: A global call for sustainability. Academy of Management Learning \& Education, 9(3):542-550. https://doi.org/10.5465/AMLE.2010.53791834

Anstätt, K. \& Volkert, J. (2016). Corporate social responsibility impacts on sustainable human development: Recent findings and consequences. Ekonomski Vjesnik, 29(1):193-210.

Araos, F. \& Ther, F. (2017). How to adopt an inclusive development perspective for marine conservation: preliminary insights from Chile. Current Opinion in Environmental Sustainability, 24:68-72. https://doi. org/10.1016/j.cosust.2017.02.008

Asian Development Bank. (2009). Conceptualizing Inclusive Development: With Applications to Rural Infrastructure and Development Assistance. https://www.adb.org/sites/default/files/evaluation-document/ 35886/files/op7-conceptualizing-inclusive-development.pdf [Accessed 21 June 2017].

Boden, R. \& Nedev, M. (2010). Employing discourse: universities and graduate 'employability'. Journal of Education Policy, 25(1):37-54. https://doi.org/10.1080/02680930903349489 
Clare, J. \& Horn, T. (2010). Sen and Sensibility. South African Journal of Philosophy, 29(2):74-84. https://doi. org/10.4314/sajpem.v29i2.57050

De George, R. (2008). An American perspective on Corporate Social Responsibility and the tenuous relevance of Jacques Derrida. Business Ethics: A European Review, 17(1):74-86. https://doi.org/10.1111/j.14678608.2008.00522.x

Del Portal, E. \& De Frutos, S. (2015). Corporate social responsibility: a critical review. Ramon Llull Journal of Applied Ethics, 6:125-136.

Deneulin, S. (2014). Constructing new policy narratives: The capability approach as normative language. In: Cornia, G.A. \& Stewart, F. (eds.). Towards Human Development. Oxford University Press. http://opus. bath.ac.uk/31885/ [Accessed 31 March 2017]. https://doi.org/10.1093/acprof:oso/9780198706083.003.0003

Elegido, J. (2009). Business education and erosion of character. African Journal of Business Ethics, 4(1):16-24.

Godemann, J., Haertle, J., Herzig, C. \& Moon, J. (2013). United Nations supported Principles for Responsible Management Education: purpose, progress and prospects. Journal of Cleaner Production, 62(2014):16-23.

Gupta, J. \& Pouw, N. (2017). Towards a trans-disciplinary conceptualization of inclusive development. Current Opinion in Environmental Sustainability, 24:96-103. https://doi.org/10.1016/j.cosust.2017.03.004

Gupta, J., Pouw, N. \& Ros-Tonen, M. (2015). Towards an elaborated theory of inclusive development. European Journal of Development Research, 27(4):541-559. https://doi.org/10.1057/ejdr.2015.30

Gupta, J. \& Vigilin, C. (2016). Sustainable development goals and inclusive development. Int Environ Agreements, 16:433-448. https://doi.org/10.1007/s10784-016-9323-z

Haertle, J. \& Miura, S. (2014). Seven years of development: United Nations-supported principles for responsible management education. SAM Advanced Management Journal, Autumn:8-17.

Hart, S. \& Milstein, M. (2003). Creating sustainable value. Academy of Management Executive, 17(2):56-67. https://doi.org/10.5465/AME.2003.10025194

Huhn, M. (2014). You reap what you sow: how MBA programmes undermine ethics. Journal of Business Ethics, 121:527-541. https://doi.org/10.1007/s10551-013-1733-z

Kuokannen, R. (2007). Reshaping the University. Responsibility, indigenous epistemes, and the logic of the gift. Vancouver: UBS Press.

Louw, J. (2015). "Paradigm change" or no real change at all? A critical reading of the U.N. principles for responsible management education. Journal of Management Education, 39(2):184-208. https://doi. org/10.1177/1052562914547965

Millar, J. \& Price, M. (2012). Making management education "moral": Employing Habermas and action research in a critical engagement with the Principles for Responsible Management Education. Paper presented at the Fifth International Society of Business Ethics World Congress (ISBEE), July 11-14. Warsaw, Poland.

Newell, P. \& Frynas, J.G. (2007). Beyond CSR? Business, poverty and social justice: an introduction. Third World Quarterly, 28(4):669-681. https://doi.org/10.1080/01436590701336507

Nussbaum, M. (2003). Capabilities as fundamental entitlements: Sen and social justice. Feminist Economics, 9(2-3):33-59. https://doi.org/10.1080/1354570022000077926

Painter-Morland, M. (2015). Philosophical assumptions undermining responsible management education. Journal of Management Development, 34(1):61-75. https://doi.org/10.1108/JMD-06-2014-0060

Podolny J. (2009). The buck stops (and starts) at business school. Harvard Business Review, 87(6):62-67.

Pouw, N. \& Gupta, J. (2017). Inclusive development: a multi-disciplinary approach. Current Opinion in Environmental Sustainability, 24:104-108. https://doi.org/10.1016/j.cosust.2016.11.013

Prandini, M., Vervoort P. \& Barthelemess, P. (2012). Responsible management education for 21st century leadership. Central European Business Review, 1(2). https://doi.org/10.18267/j.cebr.13

PRME. (2015). Inspirational Guide for the Implementation of PRME: UK and Ireland edition. Sheffield: Greenleaf.

PRME. (2017). http://www.unprme.org/ [Accessed 20 June 2017]. 
Rasche, A. \& Gilbert, U. (2015). Decoupling responsible management education:Why business schools may not walk their talk. Journal of Management Inquiry, 24(3):239-252. https://doi.org/10.1177/1056492614567315

Ritzer, G. (2003). Rethinking globalization: Glocalization/Grobalization and something/nothing. Sociological Theory, 2(3):193-209. https://doi.org/10.1111/1467-9558.00185

Robeyns, I. (2005). The capability approach: A theoretical survey. Journal of Human Development, 6(1):94-114. https://doi.org/10.1080/146498805200034266

Roudometof, V. (2016). Theorizing glocalization: Three interpretations. European Journal of Social Theory, 19(3):391-408. https://doi.org/10.1177/1368431015605443

Sen, A. (1989). Development as capability expansion. Journal of Development Planning, 19:41-58.

Sen, A. (1992). Inequality Re-examined. Oxford: Clarendon Press.

Sen, A. (1999). Development as Freedom. Oxford: Oxford University Press.

Sen, A. (2005). Human rights and capabilities. Journal of Human Development, 6(2):151-166. https://doi. org/10.1080/14649880500120491

Sobczak, A. \& Mukhi, U. (2016). The role of UN Principles for Responsible Management Education in stimulating organizational learning for global responsibility within business schools: An interview with Jonas Haertle. Journal of Management Inquiry, 25(4):431-437. https://doi.org/10.1177/1056492615618027

UN Global Compact. (2017). https://www.unglobalcompact.org/ [Accessed 31 January 2017].

United Nations General Assembly Resolution 70/1. (2015). Transforming Our World: 2030 Agenda for Sustainable Development. A/Res/70/1 (25 September 2015). https://sustainabledevelopment.un.org/ post2015/transformingourworld

Verbos, A. \& Humphries, M. (2015). Indigenous wisdom and the PRME: inclusion or illusion? The Journal of Management Development, 34(1):90-100. https://doi.org/10.1108/JMD-01-2013-0016

Walker, M. (2012). A capital or capabilities education narrative in a world of staggering inequalities? International Journal of Educational Development, 32:384-393. https://doi.org/10.1016/j.jjedudev.2011.09.003

Walker, M., McLean, M., Dison, A. \& Peppin-Vaughn, R. (2009). South African universities and human development: Towards a theorisation and operationalisation of professional capabilities for poverty reduction. International Journal of Educational Development, 21:565-572. https://doi.org/10.1016/j. ijedudev.2009.03.002

World Commission on Environment and Development. (1987). Our Common Future. http://www.undocuments.net/our-common-future.pdf [Accessed 31 January 2017].

World Economic Forum (2017). The Inclusive Growth and Development Report. http://www3.weforum.org/ docs/WEF_Forum_IncGrwth_2017.pdf [Accessed 31 January 2017]. 